\title{
Analyzing Educational Methods Regarding Human Trafficking Awareness Preferred by Students
}

\author{
Melissa Gamez ${ }^{1}$ and Jennifer Poole ${ }^{\#}$ \\ ${ }^{1}$ Sickles High School, Tampa, FL, USA \\ \#Advisor
}

$\underline{\text { ABSTRACT }}$

Human Trafficking is the emerging social-safety issue surrounding most communities across the globe. Unfortunately, due to it's untraceable nature, and free victims fearing to go public with information, human trafficking is not often discussed or warned against. The purpose of this study is to target local students from Central Florida through analyzing their preferred approaches of education regarding the basis of human trafficking. The method involved a completely anonymous online survey with ten specific questions distributed to high school and college students from across six schools in addition to interviews with two adults actively engaged in the cause of human trafficking and three chosen student participants. The questionnaire sought to collect students' passionate opinions on handling the teaching of difficult social troubles such as human trafficking. A total of 123 respondents completed the survey; $44.7 \%$ particularly desired annual presentations, $37.4 \%$ chose the inclusion of content in classes already required, and $9.8 \%$ selected mandated online courses. Interviews revealed that educational methods should not be prioritized, but instead the initiative or beginning force in means to widely spread accurate truths about human trafficking. Overall, these students from Central Florida demonstrated that in order to promote human trafficking awareness, productive conversations throughout schools as well as small incentives such as visual posters, pamphlets or resourceful packets are enough to secure an increase in knowledge of the dangers and commonality of human trafficking.

\section{Introduction}

As time evolves, new social and safety issues continue to increase, yet constantly undergo little to no awareness or publicity, among one of the most popular being Human Trafficking (HT). The Journal of Human Trafficking defines the term as, "the act of causing a person to be controlled and exploited for sex or labor or services through fraud, force, or coercion, is a grave human rights violation affecting an estimated 20.9 million or more individuals worldwide" (Atkinson et al., 2016). Even though Human Trafficking is seen worldwide, there are very few attempts or practices that have a mission to teach young students or even adults in the workforce about precautions needed to take place, signs that an individual is a trafficker or even the basics of simple knowledge regarding Human Trafficking. The lack of education is what continues the cycle of trafficking going, in that victims are blinded by the belief that an event so cruel and gruesome could not possibly happen to them. "This reality must be included in prevention work with our younger generation, particularly girls, and prevention education must begin much earlier than the average age of entry into sexual exploitation, 13 years. Education for youth about the realities of trafficking, how pimps recruit victims, and how to avoid being exploited is needed, and schools, churches, and runaway shelters are examples of appropriate settings in which to implement such programs." (Kotrla et al., 2011) stated from the Journal of Applied Research on Children: Informing Policy for Children at Risk.

The reason as to why Human Trafficking is an essential niche in my career, is due to my role as a member of an organization focusing on helping to spread awareness to middle school and high school students regarding the reality of HT; it is significantly disappointing and painful to realize that some of the youth we are reaching have 
possibly been victims, some even without understanding how, or could potentially become victims of HT due to a corrupt societal systems and insecurities we all have that make us human.

\section{Literature Review}

\section{History of Human Trafficking}

Once the initial slave trade in Portugal took place and inspired a spread of slavery to North America and eventually the world; new policies began restricting the practice of slave ownership around the 1800s. This restriction eventually led to the selling of humans for prostitution or sexual acts, which caused the International Agreement for the Suppression of "White Slave Traffic," in 1904, that protected women of every age from being sold into prostitution. Eventually this cycle of profiting from the sale of humans increased to such an extent that new terms like the ones seen today came to be to include all races, genders and age groups affected. The League of Nations took interest in this alarming issue and acted upon policies to limit HT as well as performed studies evaluating the market of prostitution to contribute towards decreasing the frequency of cases (Amy Whitman Peace et al., 2015). Furthermore, during World War II, "Over 200,000 women from various countries were sold as prostitutes by the Imperial Japanese Army" to provide comfort for Japanese army men and keep them from spreading confidential military information (Amy Whitman Peace et al., 2015).

Transferring to the current state of human trafficking, the United States has applied laws ensuring individual safety for victims and providing the appropriate resources necessary. The U.S. Congress passed the Trafficking Victims Protection Act in the year 2000, and "a subsequent revision of the TVPA enacted in 2004 provided trafficked persons with the same rights as refugees, including entitlement to health services" (Dyer et al., 2012).

\section{Human Trafficking in Florida}

For some context, Florida currently does not have a direct state law "criminalizing human trafficking; maximal prosecution of traffickers currently requires that such cases be passed to federal law enforcement investigators and the U.S. Attorney's Office in whose district the offense has been discovered", meaning cases are passed on to federal officers and not handled locally by law enforcement, which Terry Coonan, author for the Florida State University Law Review, mentions has largely been beneficial and resulted in the prosecution of many intricate cases. Florida being one of the most popular states with human trafficking cases, has also been positively affected by the TVPA considering increased collaboration with victims legally and a feeling of security for victims considering the psychological trauma suffered. As soon as they are rescued, these individuals are treated as victims and not criminals even if they participated in illegal prostitution or other acts otherwise resulting in arrest (Coonan 2003). A study from Roza Pati, author from the University of Miami Law School Institutional Repository, develops a new perspective explaining what factors lead to Florida being a hotspot for human trafficking. The major contributors are based on the environment; Florida has a huge coastline that allows for access to the United States, Miami International Airport, which is one of the largest in the world, ports known nation-wide for cruise capitals, tourist attractions such as Disney World, Orlando and South Florida; as well as home to many wealthy individuals who retire from the North. Multiculturally large areas allow for the creation of a popular market filled with services and competition. Pati also discusses the ideology that statistically the population of Florida being diverse and naturally having a culture of not following the law due to predisposition components makes for the perfect combination to attract traffickers and HT cases (Pati, 2014). Coonan and Pati both offered varying parts of human trafficking in Florida, while Coonan focused more on the legal aspect and Pati discussed environmental and cultural aspects, both explaining why Florida is the $3^{\text {rd }}$ state in the country with the most cases. 


\section{Similar Studies}

There are two sources that stood out to me as perfect mirror studies to my research, one of them administered a questionnaire to medical students in Canada to record their knowledge on HT as well as the source of where they learned the information for those that did. It was done by a group of researchers from the University of Toronto. They concluded that when students were asked about their knowledge of human trafficking, around 50\% answered "not knowledgeable" and only $0.4 \%$ answered "very knowledgeable". The same medical students when asked if they were familiar with the signs and symptoms that might help identify a victim $0 \%$ answered "very familiar" (Wong et al., 2011). This research study helps in understanding the wide lack of education in the healthcare world and uses student responses to result in the summary that there needs to be an implication of more educational practices to help students grasp the realities of HT. The second study, from Academic Psychiatry, tested two methods of teaching human trafficking information to a group of medical providers, physicians, social workers, etc. The first method was an electronic slide presentation between 25 and 60 minutes; while the second option was a 2-day training utilizing adaptation of a handbook on caring for trafficked persons. The outcome was that both methods actually performed well, Group 1 gained more general knowledge, especially on identifying a patient as a victim, however Group 2 learned more specific definitions and terms as well as the medical provider's appropriate role in assisting victims (Beresin et al., 2015). Both teams responded well to the type of information delivery and most importantly obtained valuable facts that will be used to properly account for those affected by human trafficking in healthcare facilities. Additionally, part of educating people is to make them aware of the risks of social media and help them understand that some unknown users could potentially be a trafficker, or at least to be much more careful when using social media platforms. However, David Finkelhor, member of the Association for Child and Adolescent Mental Health organization, while still believes in the importance of educational practices to prevent future cases, introduced the contrasting concept that most of the time, youth are simply living their lives and scrolling on social media platforms without a high chance of being trafficked or going down an unsafe pattern. Finkelhor suggests that yes minor safety policies need to be enforced on social media sites and that education for younger generations is important, but this does not correlate with kids always engaging in "untrustworthy actions" (Finkelhor 2014). The motive behind creating educational opportunities for younger students is to include them in the harsh conversation that is human trafficking, it is not to change their perspective on the world and make them overthink situations but to prevent this horrible cycle from continuing.

\section{Gap}

Throughout the process of gathering sources and reading capturing details on each study I didn't find any specific sources based on real student response and input. Most researchers I found focused on the pros and cons of established laws, as well as victim services and the psychological factors of HT. My question is, can appropriate and effective laws be developed without consulting the people who will be subjects to said law? My gap is giving students a voice and a choice on future education of hard social issues, by collecting data based on their own opinions to conclude an estimate of possible constructive methods to teach youth about HT. While Florida is the \#3 state in the United States with human trafficking cases, according to the University of Miami Law School (Pati, 2014), and indeed it is one of the only states with continuing regulation of existing laws such as Safe Harbor and TVPA, there are few to zero studies discussing educational practices in Florida or how to prevent HT cases in Florida. With such tourist attractions like Disney World, Orlando and Miami Airport, it's time for reflections on current methods of handling HT and ultimate change including students' feedback to provide a safer and knowledgeable environment. 


\section{Research Question}

There is a problem with prevention and educational services provided for students worldwide. Despite the Victims Protection Act and Safe Harbor legislation which declared for victims to be treated as innocent instead of criminals, the services provided after being rescued and lack of prevention laws in most states; as mentioned by Clawson and Grace, majority of programs are only about 3-6 months, not nearly sufficient for the trauma victims have undergone (Clawson and Grace, 2007). This issue has negatively impacted victims, bearing in mind limited productive resources with intentions to prevent these emerging cases, on top of scare aid and efforts for when they do occur.

Which educational methods such as programs, courses and resources; concerning human trafficking are favored by students that can be enforced towards school systems in Florida?

I hypothesize that most students will pick an educational method that provides the easiest transition for them; however, one which still provides the valuable information necessary to be aware of the issue, such as incorporating HT into the existing curriculum, for example in social studies classes. As a student myself, the more seamless the presentation, the better I learn content, unlike short online courses that only provokes one to pass through all the slides and memorize facts only to pass a certain assessment and later forget the content.

\section{Method}

Applying a mixed method using survey and interview research enables a variety of responses that aids for better understanding and analyzation of the results. The underlying purpose of this method strategy will serve to receive feedback from students on the current information they know regarding human trafficking as well as what preferred method they believe will deliver the most efficient HT awareness information. Data was collected using an online questionnaire through Google Forms plus additional interviews done via email with correspondent participants. Utilizing both interviews and surveys simultaneously cancels out the larger margin of error/ bias observed through only surveys. However, surveys are certainly needed as well because they are efficient and can simply be quantified through assigning numbers, which expands how the data can be perceived. I designed the online survey in a simple manner by asking straight to the point questions that require small thinking process and instead intuition. While explanation-type responses and longer in-depth critical questions provide a larger spectrum of responses, for my research I wanted to tap into students' most passionate opinions regarding their education. When it comes to a topic such as that of Human Trafficking education in schools there is no need for evaluation questions that might actually lead to the student simply skipping ahead or answering in a rushed style. Especially since the target audience for this research is average high school and college students, who very rarely enjoy taking part in what seems to them a random research survey. Additionally, my approach was inspired by a study in Canada targeting medical students done in 2011, which also included an even simpler questionnaire to broadly grasp the extent of knowledge the students had regarding HT (Wong et al., 2011). I found that their research provided similar data to what I am pursuing to find in my research, which are raw and effective results.

\section{Interviews Questionnaire}

Due to greater efficiency and safety precautions, all interviews were conducted through email. There were two sets of questions; depending on the participant. For adults the questions assessed their point of view regarding legal and safety actions required to make such a movement to educate schools on Human Trafficking as well as the limitations when reaching for this goal. The first question is important in the sense of at least spreading good credible sources to the students interested, which is an essential first step in the journey of transforming education. The second question holds incredible value because for under-age students, parents are a huge legal influence that could either support or neglect 
this movement. The third question is meant to figure out how HT courses could be included into the normal curriculum, which is significant because the goal is to avoid this issue being discussed in a physical educations class that most choose to do online anyways. Lastly the fourth question is regarding the school board and how they would predominantly react to such a proposition, whether in a positive or negative way.

Figure \#1. Example of the questions for Questionnaire \#1: Adults involved in HT awareness

\begin{tabular}{|l|}
\hline What programs/ resources can be given to students? \\
\hline What are limitations when teaching youth about this harsh issue? \\
\hline How can human trafficking be included in the current curriculum? \\
\hline What changes need to take place for this education practices to occur/ change? \\
\hline
\end{tabular}

The student questions addressed the role school environments have in teaching social issues as well as how they first became aware of human trafficking, which is especially important because often times we remember the first impressions of a topic/ person.

Figure \#2. Example of the questions for Questionnaire \#2: Students in High School and College

\begin{tabular}{|l|}
\hline What type of education method will help students get the most information? \\
\hline How can school help students become more aware of this issue? \\
\hline How do you think classmates will respond? \\
\hline When/how did you first hear about human trafficking? \\
\hline
\end{tabular}

\section{Survey Questionnaire}

The online survey asked basic and direct yes or no questions in means to get student's true opinion of how they felt if HT education became part of their curriculum. I mainly wanted to understand if there is currently a genuine wanting to learn this type of information, because students cannot be forced into caring. Additionally, I sought to get perspective on the most popular method picked to deliver a platform for education on human trafficking.

\section{Sample survey questions:}

\section{Figure \#3}

\begin{tabular}{|l|l|}
\hline When did you first hear about Human trafficking? \\
\hline School $\quad$ Friends \\
\hline Family $\quad$ Social Media Other \\
\hline
\end{tabular}




\section{Figure \#4}

\begin{tabular}{|l|}
\hline If you were to be taught more about human trafficking, how would you prefer it to happen? \\
\hline Once a year presentation \\
\hline Include the main issues into a class already required to graduate \\
\hline Online Course (Mandated) \\
\hline A Club \\
\hline Other \\
\hline
\end{tabular}

\section{Participants}

Participants for the online survey were all high school students, grades $9^{\text {th }}$ through $12^{\text {th }}$ along with college students. There was a large variety of males and females as well as a number of different schools involved. Furthermore for the interviews via email, the participants were: a retired Health Science teacher, trained to be a Shared Hope Volunteer Ambassador of Hope and also part of the Free Network of organizations; next a representative from the More to Life Foundation, an award winning, survivor-led, anti-human trafficking, sexual violence prevention agency that provides direct victim services, training, education, awareness events and prevention with court-appointed services to buyers in three Florida counties and with a new online learning management system for use by other organizations for other buyers nationwide, as well as critical intervention services to several communities and victims. In addition, the interview responses include three willing students who wanted to expand on their beliefs and input regarding education of HT.

\section{Procedure}

The participants who volunteered to be interviewed were contacted by email with the set of questions. This felt the most comfortable for everyone involved since it is an easier process by typing responses and avoiding having to record a face-to-face conversation and later on transcribe it as well as dealing with possible safety interventions due to the current world-wide situation. As for the online surveys, delivered through Google forms; they were distributed on social media by posting the link for everyone to access. All participants were reassured that answers were anonymous, and their identity was not ever recorded. They were also all notified that their responses would be part of research and that they in no means are required to take part in either the survey or interview. I made sure to edit the survey so that no participants could retake or change any results by requiring email addresses (that I had zero access to), this was a decision made to ensure credibility and little to no interference with the finishing results. I chose to use social media as a tool to spread my survey because it attracts a large and diverse audience that is quickly effective as compared to handing out loose forms that could easily be damaged or lost. Furthermore, I chose to make each question on the online survey required because this would ensure each participant to fully complete the survey in an organized manner as well as cancel out any possible participants with the desire to submit an empty form or respond with inappropriate answers on purpose to alter with the research. Once the data was collected all responses were processed through an Excel spreadsheet, this technique will provide me with a laid-out overview of responses, allowing for productive data analysis and conclusions.

\section{Results \& Data Analysis}

The survey I conducted yielded a total of 123 responses from students attending high school or college: approximately ages 14-22. They all attended a variety of six schools in Central Florida; females made up 74\% of participants, males 
$25.2 \%$ and $0.8 \%$ of respondents answered, "Prefer not to say". Prior to participation, all students signed a consent form ensuring the confidentially of responses and anonymous nature of the study.

When did you first hear about Human trafficking?

123 responses

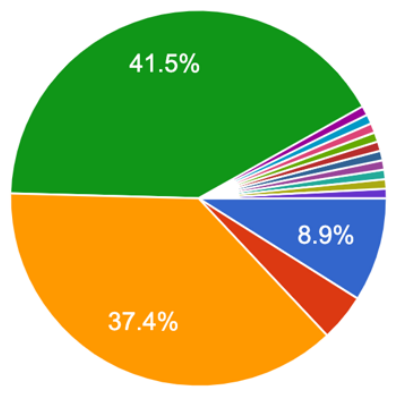

School

Friends

Family

Social Media

Unsure

Entertainment Media

Research

News and research on my own

$1 / 2$

Figure \#5

As seen above in figure \#5, students were asked, "When did you first hear about Human Trafficking?" Majority answered from Social Media (41.5\%) and Family (37.4\%). This depicts an interesting conclusion that must be prioritized, since the data suggests that social media and family are the most common information outlets; it is essential that we build these communities to deliver accurate and current results. Social media has allowed us to quickly access and be exposed to valuable material; it has become for many, a news source. However, it is particularly concerning that participants chose it over the other options to be the place where they first heard about HT, considering the strong bias and exaggerated evidence presented in different social media platforms. This leads me to believe that a possible new area to research is how to modify social media in a way that would guarantee valid information about sensitive social issues such as Human Trafficking. Learning about HT from family can similarly carry one-sided opinions, especially since this topic is strange to openly discuss; parents could potentially shelter their children and believe they are protecting them when in reality ignorance puts individuals at risk of being a victim. While of course there are significant positives to learning about HT through social media and family such as privacy and even personal stories about survivors, school should be a major source to accurately start the conversation with students and later inspire talks at home and individual research on social media. School is meant to be a neutral zone without underlining bias or potential misinformation as well as a safe space for those with uninterested households and/ or lack of social media exposure that don't have access to this information. Lastly, Figure \#5 suggests that a preferred method to spread information on HT could be through either social media or family discussions, provided there are standards for its content and delivery. 


\section{How did you feel about the Mental Health course we all had to take online last year?}

123 responses

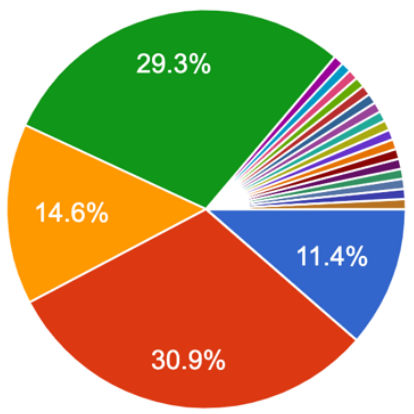

I thought it gave me really good inform...

I learned some things but mainly skipp...

I hated it

I knew everything on there

I didn't take a mental health course

I think it retold us a lot of information...

i don't even think $i$ took any sort of me...

it was useless, it was telling us inform...

$1 / 3$

\section{Figure \#6}

Furthermore, Figure \#6 demonstrates the response after students were asked, "How did you feel about the Mental Health course we had to take online last year?" The most popular responses depicted: learning some things but skipping through most information (30.9\%), already knowing everything (29.3\%), hating doing it (14.6\%), and $11.4 \%$ said it gave them some good information. The course being asked about is a mandatory online assessment including surveys regarding mental health, alcohol, and drugs which was assigned by the state of Florida to students $\mathrm{K}-12^{\text {th }}$ with means to accommodate with increased rates of mental health issues, alcohol and drug consumption by minors. Figure \#6 implies that students associate negative feelings towards learning content through unnecessary small courses that don't actually accomplish any long-term goals. If these were the results for even more common dangers such as drugs, alcohol and mental health; I can't imagine that shoving human trafficking content into a mandatory state course would raise awareness or promote safety.

If you were to be taught more about human trafficking, how would you prefer it to happen? 123 responses

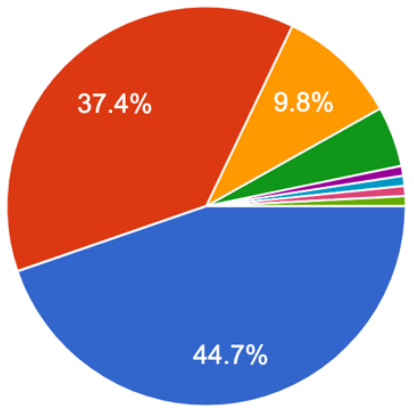

Once a year presentation

Include the main issues into a class already required to graduate

Online course (mandated)

A club

A documentary would probably be effective

Public speaker

Presentations often as could be done

It could be intergraded into like a histo...

\section{Figure \#7}

Figure \#7 presents students being questioned, "If you were to be taught more about human trafficking, how would you prefer it to happen"? $44.7 \%$ chose a once-a-year presentation, $37.4 \%$ picked to include the content into a 
class already required to graduate and $9.8 \%$ decided that a mandated online course would be best. I noticed that the two most popular responses were the most inclusive and collaborative; a presentation would entail all students per grade; and the second option includes everyone in a specific class. However, the other selections seem to require individual work. This is a conclusion that serves my research significantly; it insinuates that students feel the most comfortable acquiring unpleasant knowledge as a group, with people whom they have daily interactions. Moreover, I became aware that learners chose the most seamless and conventional methods, which would be least likely to disrupt normal routines. As a student myself, I can with certainty vouge for this, taking into account the difficulty of actively wanting to learn information during periods of time outside of one's regime at which point it is considered extra, meaningless work. This specific data contributes largely to my research question, which sets out to find optimal methods for students to learn in depth information about HT. Lastly, it became clear that Figure \#6 and \#7 share a common relationship; it seems to be that does who selected, the mental health course to give them good information also chose a mandatory online assessment to teach them about HT. While those who did not receive value from the mental health course, likely selected a presentation or incorporating material into a class already required for graduation.

Figure \#8: Interview Adult Responses

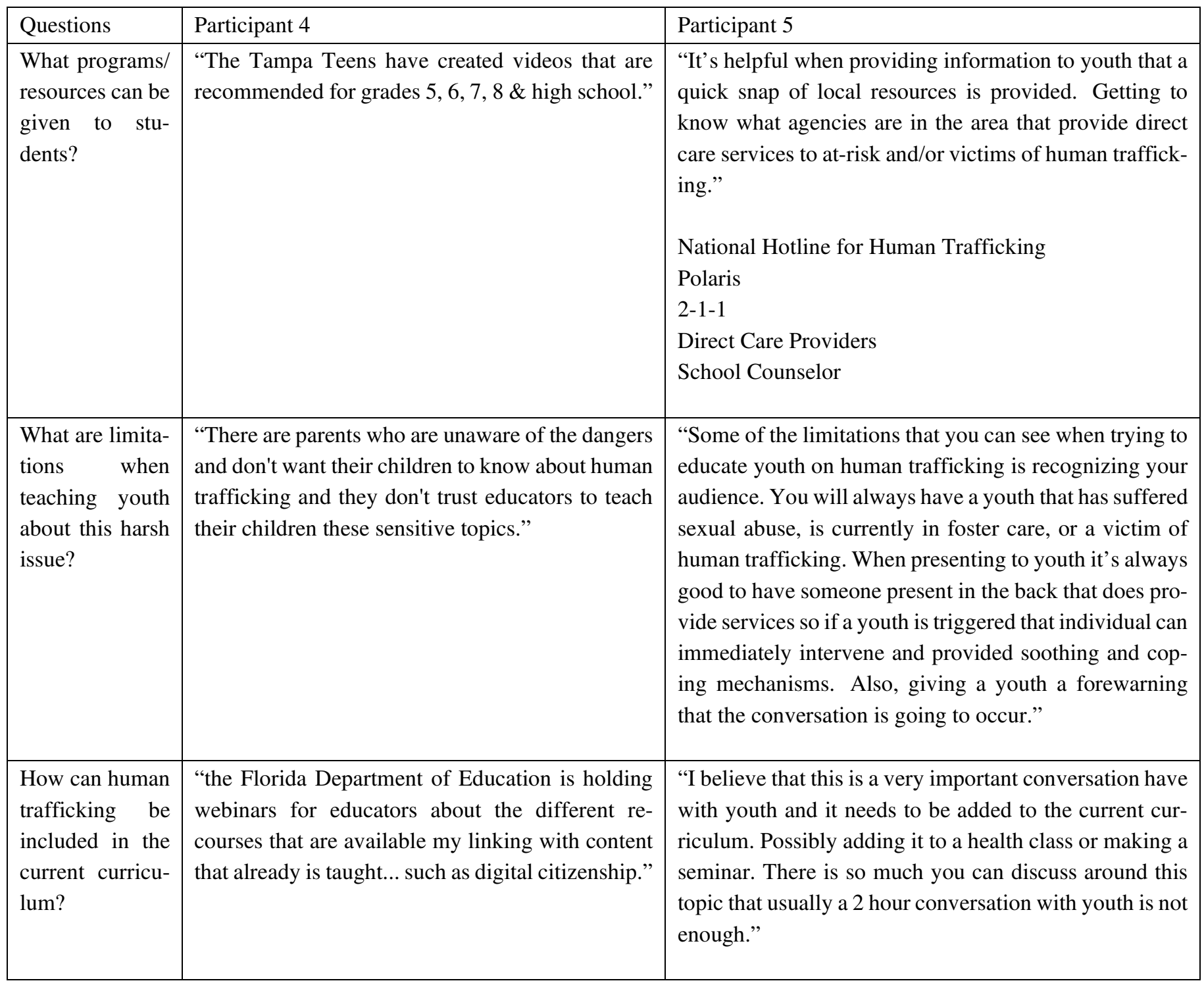




\begin{tabular}{|c|c|c|}
\hline $\begin{array}{l}\text { What changes } \\
\text { need to take } \\
\text { place for this ed- } \\
\text { ucation prac- } \\
\text { tices to occur/ } \\
\text { change? }\end{array}$ & $\begin{array}{l}\text { "Human Trafficking has many dynamics... Legal } \\
\text { issues, public health issues, safety issues etc. on a } \\
\text { "funny" note It DOES NOT belong in PE clas- } \\
\text { ses Yet that is where it has been assigned in Hills- } \\
\text { borough County" }\end{array}$ & $\begin{array}{l}\text { "Getting everyone on board to see the importance that } \\
\text { this needs to be a topic in the schools. Not just a } 2 \text { hour } \\
\text { conversation but a topic included in a class for several } \\
\text { days. Provide more education around the schools, have } \\
\text { assemblies, posters, parent education nights. Making it } \\
\text { a mandatory discussion. In the schools not only for the } \\
\text { students, but for the teachers, counselors, and profes- } \\
\text { sionals in the schools." }\end{array}$ \\
\hline
\end{tabular}

By analyzing Figure \#8, placed above, I notice that the adult participants share a common concern for how the content is handled, it will not be merely enough to establish minor hour conferences, which primarily exist to meet state benchmarks. Especially considering the frequency of victims in schools, who can easily be triggered, or begin to feel uncomfortable in the midst of these conversations. A noteworthy occurrence to me is that the resources shared by these trained adults are publicly available to all in the nation. Yet, I very rarely see them mentioned in educational facilities. I would agree also that a second area to research from this paper is, how to properly grasp students' attention when displaying important resources to issues they may be susceptible to. I consider this conclusion to be of prime relevance because, school districts can promote resources and websites as much as possible; however, if the actual individuals do not care, progress will not be made- which puts us back to ground zero. This data additionally proposes the underlying limitation of reaching youth; being the parents. In order to accurately move forward with HT education, the main component is assuring support from home. It's difficult to gather all parents' approval, as well as their contribution in personally teaching their kids. This particular assumption correlates with Figure \#5, which depicted "Family" to be one of the top information sources for students surveyed. Which once again emphasizes the key role of parental assistance in spreading relevant content on Human Trafficking.

Figure \#9: Interview Student Responses

\begin{tabular}{|c|c|c|c|}
\hline Questions & Participant 1- High School & Participant 2- College & Participant 3- High School \\
\hline $\begin{array}{l}\text { What type of education } \\
\text { method will help stu- } \\
\text { dents get the most in- } \\
\text { formation? }\end{array}$ & $\begin{array}{l}\text { "I think it is important to re- } \\
\text { member that every student is } \\
\text { different and absorbs infor- } \\
\text { mation in different ways. So re- } \\
\text { gardless of how you go about } \\
\text { this education I think it needs to } \\
\text { be offered in a few different } \\
\text { ways. For example there are Au- } \\
\text { ditory, Visual, and Hands on } \\
\text { learners. So I think you should } \\
\text { provide some visual resources } \\
\text { such as pamphlets and posters } \\
\text { around the school, auditory re- } \\
\text { sources like speakers to come } \\
\text { give presentations, and some } \\
\text { sort of course that maybe } \\
\text { doesn't have to be mandatory } \\
\text { but should at least be offered." }\end{array}$ & $\begin{array}{l}\text { "An education that requires stu- } \\
\text { dents to be in person to actively } \\
\text { participate in instruction and } \\
\text { hands-on learning is the most ef- } \\
\text { fective way for students to get } \\
\text { the most information out of any } \\
\text { curriculum. Therefore, in rela- } \\
\text { tion to the awareness of human } \\
\text { trafficking, engaging discus- } \\
\text { sions and presentations that re- } \\
\text { quire students to partici- } \\
\text { pate would be and has already } \\
\text { proven to be the most effective } \\
\text { way for students to become } \\
\text { aware about human trafficking." }\end{array}$ & $\begin{array}{l}\text { "Being a student who attends } \\
\text { high school who doesn't have } \\
\text { any access to this issue, not be- } \\
\text { ing in any clubs that discuss it, I } \\
\text { believe that we should incorpo- } \\
\text { rate it into class curriculum. Ei- } \\
\text { ther health, Social studies, an as- } \\
\text { sembly, or even a specialized } \\
\text { course such as the one we took } \\
\text { for drug or alcohol use, would } \\
\text { be very beneficial to getting the } \\
\text { information out". }\end{array}$ \\
\hline
\end{tabular}




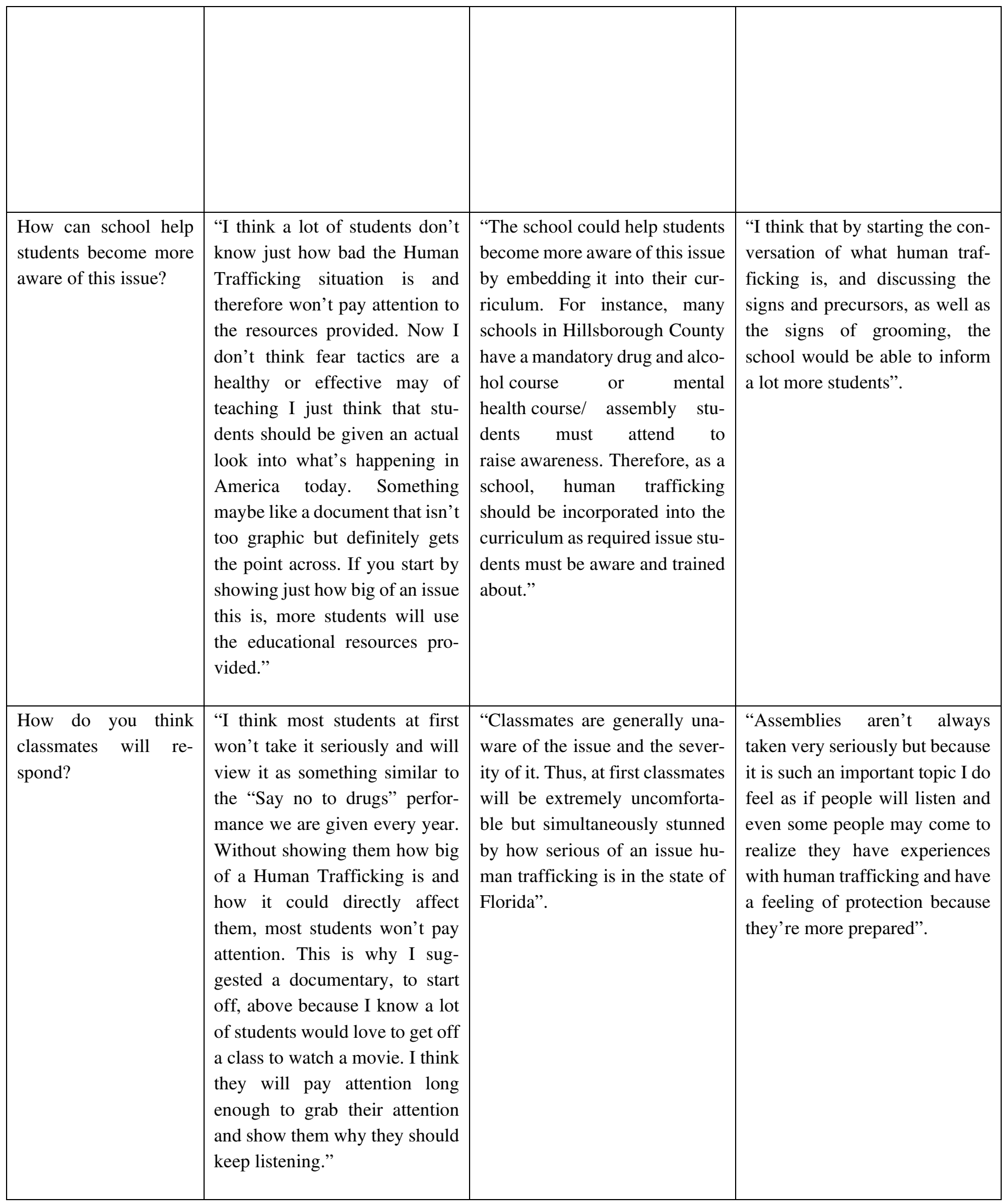




\begin{tabular}{|c|c|c|c|}
\hline $\begin{array}{l}\text { When/how did you } \\
\text { first hear about human } \\
\text { trafficking? }\end{array}$ & $\begin{array}{l}\text { "I have always been told since I } \\
\text { was a young girl to never talk to } \\
\text { strangers and to stay away from } \\
\text { being around men alone but I, } \\
\text { never quite understood what } \\
\text { could happen if I, was taken. I } \\
\text { have always seen posters around } \\
\text { school and at the airport about } \\
\text { reporting suspicious activity } \\
\text { with the frowning child on it, } \\
\text { but it wasn't until Tiktok that I } \\
\text { actually found out just how big } \\
\text { of a problem Human Trafficking } \\
\text { was. Then Mellissa and I had a } \\
\text { conversation which really } \\
\text { brought to my attention just how } \\
\text { important spreading awareness } \\
\text { is to help. After those two initial } \\
\text { points of contact I started doing } \\
\text { some of my own research but } \\
\text { would love to learn more." }\end{array}$ & $\begin{array}{l}\text { "I first heard about human traf- } \\
\text { ficking years ago when I was in } \\
\text { middle school. However, I did- } \\
\text { n't fully come to an understand- } \\
\text { ing of it until about a year ago } \\
\text { through an organization called } \\
\text { the Tampa Teens in which I am } \\
\text { not only a part of, but also a } \\
\text { founding member." }\end{array}$ & $\begin{array}{l}\text { "I first heard about it in fifth } \\
\text { grade from my mom, we had } \\
\text { previously had conversations } \\
\text { about kidnapping and my mom } \\
\text { told me what human trafficking } \\
\text { was and the difference between } \\
\text { it and kidnapping. I was in fifth } \\
\text { grade so I didn't really compre- } \\
\text { hend all of it but obviously as I } \\
\text { got older I learned more about it } \\
\text { from my mom and even just } \\
\text { googling". }\end{array}$ \\
\hline
\end{tabular}

Figure \#9, demonstrates the student interview responses, in which raw and honest opinions were shared that facilitated me to realize the stance of my original hypothesis. I deeply believed that students would prefer HT education to be included into the curriculum, which was mostly the case; however it is transparent that what is needed to initiate interest in the information is a shock factor, as mentioned by participants 1,2 and 3. These particular interviews also made me come to the conclusion that starting the conversation in any form will be the most effective, whereas I was worried initially that a huge step needed to occur quickly in order to view any change at all. It is interesting to dissect each participant's point of view; they all agree that HT information must be delivered and shared loudly; however, each respondent differed on the method approach. Participant 1 suggested personal, and specialized learning that would connect with all type of learners; participant 2 believes in an intense hands-on approach that motivates all students to experience the severity of the issue and discuss openly. Whereas participant 3 shares a laid-back tactic involving general talks and/ or having specific mandated courses that produce relevant facts and information on human trafficking. The difference of opinions regarding preferred strategies is what I mainly suspected would happen. We all learn in different speeds, environments, and have comfortable manners already developed to learn new content. That is a natural conclusion from this study, which is why the purpose is a beginning phase of spreading safety measures that prepare the student population in Florida to be aware and feel secure to handle possible at-risk situations related to human trafficking whether that is towards themselves or anyone else. Participants 1,2, and 3 additionally agree that schools must at least enforce spreading HT material whether that is through pamphlets, posters, required online assessments, conferences, etc. They are responsible for making the facility into a safe place that promotes cautious behavior inside and outside of the facility. Student interviews accommodated even further for my gap, since these were all viewpoints shared by students in Central Florida that significantly supported the research topic in question. 


\section{Conclusion}

From my research, I came to the new understanding insinuating that there is no clear-cut educational method preferred by students. It seems that their main interest is simply acquiring some amount of knowledge on the topic, in the easiest manner. Moreover, family and social media (Figure \#5) are commonly suggested to be the most prevalent sources of information, that students would actually consider taking into account. I became aware that while yes, schools must move forward with trained counselors, ample info pamphlets, posters, clubs, etc.; unfortunately, survey responses and interviews presented in this research suggest that classmates will not take school-mandated material seriously. However, annual presentations, and small segments of HT incorporated into possibly history or literature classes indicate to be effective strategies in starting a mutual conversation on the topic (Figure \#7). There appears to be no correlation between specific perfected methods causing the most impact on the spread of information. This understanding should be alleviating for facilities with limited monetary or assistance resources without the means to transform their education approach since the core value implied to best target the safety of students is beginning the talk in an engaging and respectful manner.

\section{Limitations}

This research was particularly restricted due to under-representation caused by a smaller sample size, underlying survey-based bias, and lastly COVID-19- related imparities. The conclusions drawn are only a reflection of 123 Central Florida students, which does not represent the full population of the student body. This could have affected the results of my research considering students around the country have specific niche needs dependent on their area and access to resources; a larger sample size could have projected more concise and direct patterns. Survey- bias is a secondary factor present in almost all survey-based studies, even though I tried reaching schools from all social economic and ethnic backgrounds, majority of participants represented predominantly white, suburban, and privileged neighborhoods with slightly decreased chances of getting trafficked. Whereas downtown areas in Central Florida have slightly higher chances of HT reaching them due to economic and supply vulnerabilities. Those type of participants might have had drastic or minor changes in responses due to increased exposure to the world of HT. Lastly, the emergence of the COVID-19 virus implemented difficulties for my research, considering that I could not engage in face-to-face interactions or encourage classmates as much or easily as opposed to the normal environment. It was especially challenging to reach an audience from home, even though social media is always an available outlet, the student morale was down and most did not want to take part in survey completion. In past times, I could have used verbal incentives to quickly gather respondents and observe their reactions and comments.

\section{Implications}

As previously mentioned, there are two particular studies that contrast and complement the gap of my research well. The first being my mirror study, performed by researchers from the University of Toronto, in which medical students were asked simple questions regarding HT, mainly focused on collecting a final spectrum that demonstrated if the participants had any knowledge on human trafficking at all through 'yes' or 'no' assessments (Wong et al., 2011). My research contributed in addition to said study by going a step further and asking the student body in a different area what methods they perceived would genuinely help spread awareness about

the topic of human trafficking. Additionally, the survey and interview questions in my research provided detailed, and unfiltered feedback from students that could not have been achieved through a method of 'yes' or 'no' questionnaires. This is a quality that differentiates my research from previous studies and adds to the greater body of literature, through the use of student feedback, rarely done in this current avenue of research regarding education of HT. Furthermore, the second study guided by Academic Psychiatry, tested two approaches of educational training towards 
medical and counseling staff. The first method was a slide presentation with a duration of 25-60 minutes, whereas the second option was a 2-day session utilizing content from handbooks on caring for trafficked persons. Resulting in both positive outcomes, each group acquired specific advantages and information; neither proved to be superior or less/ more effective (Beresin et al., 2015). My research predominantly supports this conclusion; in that my overall analysis pointed towards a middle ground where each method of education has individual advantages, however, they all achieve the common goal of spreading awareness and ultimately teaching students about human trafficking. It seems that equally for professional adults and high school/ college students any initiative can make a change, reach the audience and keep everyone safe from the dangers of HT.

\section{Further Research}

Performing this research inspired my thinking of possible paths that next researchers could further analyze and investigate. One of the troubles I found during the evaluation of how students heard about human trafficking, is that social media recently has been a very biased and at times untruthful environment, considering individuals have more interest in spreading their personal opinions instead of facts and helpful information. With young adults already experiencing vulnerabilities online, there is no place for false news and one-sided conclusions. Following researchers should look into how the displaying of sensitive real-life issues such as human trafficking on social media positively or negatively impacts minors' perception of said problems. This fresh conclusion would expand the greater area of research and possibly inspire social media companies to better manage fragile content posted. Additionally, throughout my research I ran into the indication that students don't value cautious advice unless they have been or feel that they could be personally affected by specific matters. This evidence along with my taking part in a collective meeting with the U.S. Institute Against Human Trafficking and Congressmen Bilirakis, where addressing HT at the local level was discussed, strongly pushed me to believe that prevention methods need to be thoroughly explored. How can those who deeply suppose they will not be affected by HT or other troubling instances be advised effectively? What does prevention entail exactly besides education? These assessments need to be answered by forthcoming researchers. For instance, Suncoast Credit Union requires all workers to undergo HT training in order to appropriately identify major signs or possible victims. Which raises the question if all establishments should follow such policies? Each piece of contribution signifies a step further taken that will eventually complete the patchwork of preventing human trafficking.

\section{Acknowledgments}

I would like to express my dearest gratitude to my primary supervisor, Jennifer Poole who guided me through the entirety of this project. Thank you for all of the valuable input! I would additionally like to thank my friends and family for all the support and assistance.

\section{References}

Amy Whitman Peace, Studies, D., \& Gray, D. H. (2015). Transnational Human Trafficking. Global Security Studies, 6(3). http://globalsecuritystudies.com/Whitman\%20Trafficking\%20-AG.pdf

Atkinson, H. G., Curnin, K. J., \& Hanson, N. C. (2016). U.S. State Laws Addressing Human Trafficking: Education of and Mandatory Reporting by Health Care Providers and Other Professionals. Journal of Human Trafficking, 2(2), 111-138. https://doi.org/10.1080/23322705.2016.1175885 
Beresin, E. V., Milligan, T. A., Balon, R., Coverdale, J. H., Louie, A. K., \& Weiss Roberts, L. (2015, December 21). Physician Wellbeing: A Critical Deficiency in Resilience Education and Training. Academic Psychiatry. https://link.springer.com/content/pdf/10.1007/s40596-015-0475-X.pdf

Clawson, H., \& Grace, G. (2007). Finding a Path to Recovery: Residential Facilities for Minor Victims of Domestic Sex Trafficking. 10. https://digitalcommons.unl.edu/cgi/viewcontent.cgi? article=1009\&context=humtraffdata Coonan, T. S. (2003). Human Rights in the Sunshine State: A Proposed Florida Law on Human Trafficking. Retrieved 2020, from https://ir.law.fsu.edu/cgi/viewcontent.cgi?referer=https://scholar.google.com/scholar?hl=en\&as_sdt=0,10\&qsp=11\& $\mathrm{q}=$ florida law human trafficking\&qst=br\&httpsredir $=1 \&$ article $=1318 \&$ context $=\mathrm{lr}$ Dyer, K., Dickey, N., Smith, S., \& Helmy, H. (2012). Human Trafficking in Florida: The Role of Applied Anthropology in Addressing the Problem and Response. Practicing Anthropology, 34(4), 24-28. https://doi.org/10.17730/praa.34.4.g632r1j2m4w60413

Finkelhor, D. (2014). Commentary: Cause for alarm? Youth and internet risk research—a commentary on Livingstone and Smith (2014). Journal of Child Psychology and Psychiatry, 55(6), 655658. https://doi.org/10.1111/jcpp.12260.

Kotrla, K., Wommack, B., \& Ann. (2011). Sex Trafficking of Minors in the U.S.: Implications for Policy, Prevention and Research. Journal of Applied Research on Children: Informing Policy for Children at Risk, 2. https://files.eric.ed.gov/fulltext/EJ1189039.pdf

Pati, R. (2014). Human Trafficking: An Issue of Human and National Security. https://repository.law.miami.edu/cgi/viewcontent.cgi?article=1057\&context=umnsac

Wong, J., Hong, J., P Leung, P Yin, \& Stewart, D. (2011). Human Trafficking: An Evaluation of Canadian Medical Students' Awareness and Attitudes. Education for Health, 24(1), 501.

https://www.educationforhealth.net/article.asp?issn=1357$\underline{6283}$; year $=2011 ;$ volume $=24 ;$ issue $=1 ;$ spage $=501 ;$ epage $=501 ;$ aulast $=$ Wong 